\title{
Characterization of morphology and resistance to Blumeria graminis of winter triticale monosomic addition lines with chromosome 2D of Aegilops tauschii
}

\author{
M. Majka $^{1} \cdot$ M. Kwiatek ${ }^{1} \cdot$ J. Belter ${ }^{1} \cdot$ H. Wiśniewska ${ }^{1}$
}

Received: 25 May 2016/ Accepted: 29 June 2016/Published online: 12 July 2016

(c) The Author(s) 2016. This article is published with open access at Springerlink.com

\begin{abstract}
Key message Allocation of the chromosome 2D of Ae. tauschii in triticale background resulted in changes of its organization, what is related to varied expression of genes determining agronomically important traits.

Abstract Monosomic alien addition lines (MAALs) are crucial for transfer of genes from wild relatives into cultivated varieties. This kind of genetic stocks is used for physical mapping of specific chromosomes and analyzing alien genes expression. The main aim of our study is to improve hexaploid triticale by transferring D-genome chromatin from Aegilops tauschii $\times$ Secale cereale $(2 n=4 x=28$, DDRR). In this paper, we demonstrate the molecular cytogenetics analysis and SSR markers screening combined with phenotype analysis and evaluation of powdery mildew infection of triticale monosomic addition lines carrying chromosome 2D of Ae. tauschii. We confirmed the inheritance of chromosome $2 \mathrm{D}$ from the $\mathrm{BC}_{2} \mathrm{~F}_{4}$ to the $\mathrm{BC}_{2} \mathrm{~F}_{6}$ generation of triticale hybrids. Moreover, we unveiled a high variable region on the short arm of chromosome 2D, where chromosome rearrangements were mapped. These events had direct influence on plant height of hybrids what might be connected with changes at Rht8 loci. We obtained 20 semi-dwarf plants of $\mathrm{BC}_{2} \mathrm{~F}_{6}$ generation carrying $2 \mathrm{D}$ chromosome with the powdery mildew resistance, without changes in spike morphology, which can be used in the triticale breeding programs.
\end{abstract}

Communicated by I. Hwang.

M. Majka

mmaj@igr.poznan.pl

1 Institute of Plant Genetics, Polish Academy of Sciences, Strzeszyńska 34, 60-479 Poznań, Poland
Keywords Aegilops · In situ hybridization · Monosomic alien addition lines · Plant height · Powdery mildew · Triticale

\section{Introduction}

The world production of hexaploid triticale $(\times$ Triticosecale Wittm.) is rising from 473 thousand tonnes in 2012 to 820 thousand tonnes in 2014 (FAOSTAT 2015). The worldwide expansion of triticale exposed the crop to a variety of stressful environmental conditions (Arseniuk and Góral 2015). From the other side, the global market requires diversified forms of triticale considering grain quality, resistance against biotic and abiotic stresses, and plant morphology. Considering triticale breeding, one of the main goals is to transfer genes of interest from wild relatives into cultivated varieties. The ability of triticale to be crossed with related species allows the addition of the whole genomes or individual alien chromosomes to the triticale complement. Monosomic alien addition lines (MAALs) are genotypes with an alien chromosome from a donor species added to the genome of recipient species. This kind of genetic stocks is widely used for physical mapping of specific chromosomes (Kynast et al. 2004) and analyzing alien genes expression (Cho et al. 2006). The production of alien addition lines and the introgressions with alien chromosome segments carrying target traits can be induced by homoeologous recombination or the gametocidal effect (Kwiatek et al. 2016a, b).

Ae. tauschii is a wild, diploid goatgrass (donor of D-genome to bread wheat), characterized by wide genetic variation and close related to the species of the Triticeae tribe. Because of this relationship and variety of genes, this species has been exploited by various groups around the 
world especially for wheat improvement (Ogbonnaya et al. 2005). The chromosome 2D of Ae. tauschii is bearing two important agronomically genes $R h t 8$ and $P m 43$ as well as bh-D1 a multirow spike recessive allele (alias mrs1) determining the supernumerary spikelets trait (Jia et al. 2013). The variation of genes on one chromosome indicates that it is the most valuable one for breeding improvement of Triticeae species.

In triticale breeding programs, reduction of plant height may affect to a better partitioning of assimilates for the benefit of the spike and reducing the risk of lodging what leads to increasing of grain yield (Foulkes et al. 2011). Recently, the height of the cereal plants can be changed by breeders through the use of dwarfing or semi-dwarfing genes. The phenomenon of introduction of the reduced height (Rht) genes into bread wheat (Triticum aestivum L.) was the major event of 'green revolution' (Hedden 2003) and is widely used in wheat breeding. Particulary, the modest height-reducing gene Rht 8 may be suitable to reduce the height of mature plants without compromising early plant growth. The genetic linkage maps presented by Korzun et al. (1998) place the wheat microsatellite marker WMS 261 (Xgwm261 in map of Somers et al. 2004) $0.6 \mathrm{cM}$ distal to Rht8 on the short arm of chromosome 2D.

The most important trait for breeding is yield. One of the factors determining this agronomic feature is the amount of grain per plant, which indicates the productiveness of given genotypes. It especially depends on the architecture of the inflorescences. The number of spikelets per rachis node is a key taxonomic trait of the Triticeae tribe. The wheat and rye spike normally bears one spikelet per rachis node, and the formation of supernumerary spikelets (SS) is rare. The loci responsible for the 'multirow spike' or MRS trait in wheat and the 'monstrosum spike' trait in rye are under the control of a recessive allele at a single locus. The Mrs1 locus is located on chromosome 2DS and the Mo1 locus on chromosome 2 RS. Furthermore, there is also identified a homologous loci on the chromosome $2 \mathrm{AS}$ of hexaploid, tetraploid, and diploid wheats.

In the last few years, the cultivation of triticale was limited due to the infection by Blumeria graminis $\mathrm{f}$. $\mathrm{sp}$. tritici which caused powdery mildew (Pm) (Czembor et al. 2013). Therefore, resistant varieties are the most feasible means of controlling the disease and reducing yield losses. To date, $54 \mathrm{Pm}$ resistance genes where transferred from the wild relatives to wheat (Zhan et al. 2014). However, in the case of triticale, only one work reports the positive transfer of Pm13 gene from Aegilops variabilis (Kwiatek et al. 2016a). Ae. tauschii genomes constitute a great source of $P m$ resistance because of the occurrence of Pm2, Pm34, and Pm35 genes on chromosome 5D and Pm19 on chromosome 7D (Genesymbol, McIntosh et al. 2003). Furthermore, Jia et al. (2013) mapped Pm43 gene in Ae. tauschii chromosome 2D, in which the origin source has heretofore been Th. intermedium. So far, Th. intermedium resistance gene (later called $P m 43$ ) was recently found in partial amphiploids with wheat, in the substitution line $2 \mathrm{~J}(2 \mathrm{D})$, in which a J-chromosome of Th. intermedium was substituted for chromosome 2D in wheat (Liu and Wang 2005; Liu et al. 2005) as well as transfer to wheat using a resistant partial amphiploid as a bridging parent in crosses with susceptible wheat lines.

Our main goal was to produce triticale MAALs carrying 2D chromosome of Ae. tauschii. For that reason, we have introduced D-genome chromosomes into triticale using Aegilops tauschii Coss. (DD, $2 n=2 x=14) \times$ S. cereale (RR, $2 n=2 x=14$ ) amphiploid forms to hybridize with triticale cv. Bogo (Kwiatek et al. 2015). The present study aimed: (1) to characterize the chromosome composition of the $\mathrm{BC}_{2} \mathrm{~F}_{4}$ to $\mathrm{BC}_{2} \mathrm{~F}_{6}$ generations of Ae. tauschii $\times$ triticale hybrids; (2) to verify the D-genome composition with selected SSR markers in hybrid plants, and (3) to evaluate the influence of the D-genome introgression onto important agronomic traits, including plant height, spike morphology, and resistance to powdery mildew in comparison with winter triticale cultivar Bogo.

\section{Materials and methods}

\section{Plant material}

Glasshouse experiments were carried out in three subsequent vegetation seasons at the Institute of Plant Genetics, Polish Academy of Sciences in Poznan, Poland. Seeds of Aegilops tauschii Coss. (D51; $2 n=2 x=14$; DD), $S$. cereale (Strzękęcińskie; $2 n=2 x=14$; RR) and $\times$ Triticosecale Wittm. (Bogo; $2 n=6 x=42$; AABBRR) originating from the collection of the Institute of Plant Genetics. The Ae. tauschii $\times S$. cereale amphiploids $(2 n=4 x=28$; DDRR $)$ were obtained using embryo rescue by Sulinowski and Wojciechowska of the Institute of Plant Genetics (data unpublished). The $\mathrm{F}_{1}($ Ae. tauschii $\times S$. cereale $) \times$ triticale hybrids were obtained by crossing of triticale cv. Bogo with Ae. tauschii $\times S$. cereale amphiploids as a pollinator. Backcrosses with the triticale as a male parent were used to achieve following generations $\left(\mathrm{BC}_{1} \mathrm{~F}_{1}\right.$ and $\left.\mathrm{BC}_{2} \mathrm{~F}_{1}\right)$ and further self-crossed to produce following generations of $\mathrm{BC}_{2} \mathrm{~F}_{2}$ to $\mathrm{BC}_{2} \mathrm{~F}_{6}$ hybrid plants. Seeds of $T$. aestivum cv. Chinese Spring were kindly supplied by the National Small Grains Collection (USDA-ARS).

\section{Probe labeling}

Total genomic DNA was extracted from fresh leaves of $A e$. tauschii (DD), Triticum monococcum ( $\left.\mathrm{A}^{\mathrm{m}} \mathrm{A}^{\mathrm{m}}\right), \quad$ Ae. 
speltoides (BB), S. cereale (RR), and triticale 'Bogo' (AABBRR) using GeneMATRIX Plant and Funghi DNA Purification Kit (EURx Ltd.). Genomic DNA from Ae. tauschii and T. monococcum were labeled by nick translation (using NickTranslation Kit, Roche, Mannheim, Germany) with tetramethyl-5-dUTP-rhodamine (Roche) or digoxigenin-11-dUTP (Roche) depending on the visualization concept. Blocking DNA from triticale, Ae. speltoides and S. cereale, was sheared to fragments of 5-10 kb by boiling for 30-45 min and used at a ratio of 1:50 (probe:block). The 5S rDNA and 25S rDNA as well as pSc119.2 and pAs1 probes were obtained as have been described by Kwiatek et al. (2016a, b) and labeled with tetramethyl-rhodamine-5-dUTP (Roche), digoxigenin-11dUTP (Roche), digoxigenin-11-dUTP (Roche), and tetramethyl-rhodamine-5-dUTP (Roche), respectively. Digoxigenin detection was made using anti-digoxigeninfluorescein antibody (Roche).

\section{Chromosome preparation and in situ hybridization}

Germination, metaphase accumulation, and fixation procedures were carried out according to Kwiatek et al. (2016a). The chromosome preparations were made according to Hasterok et al. (2006). FISH and GISH experiments were performed for the identification of chromatin introgression. The analysis of genomic composition of hybrid plants was carried on the mitotic chromosomes of root meristems. Four probes (5S rDNA, 25S rDNA, pSc119.2, and pAs1) were subjected to in situ hybridization on the same chromosome preparations. First FISH was made according to Książczyk et al. (2011) with minor modifications of Kwiatek et al. (2013) using 5S rDNA (pTa794) and 25S rDNA (used for the detection of 25-5.8-18S rDNA loci). The hybridization mixture $(40 \mu \mathrm{l}$ per slide) contained $90 \mathrm{ng}$ of each probe in the presence of salmon sperm DNA, $50 \%$ formamide, $2 \times \mathrm{SSC}$, and $10 \%$ dextran sulphate, and was denatured at $75{ }^{\circ} \mathrm{C}$ for $10 \mathrm{~min}$ and stored on ice for $5 \mathrm{~min}$. Chromosomal DNA was denatured in the presence of the hybridization mixture at $75^{\circ} \mathrm{C}$ for $5 \mathrm{~min}$ on a heating table (Medax) and allowed to hybridize overnight at $37{ }^{\circ} \mathrm{C}$. Digoxigenin detection was made using anti-digoxigenin-fluorescein antibody (Roche). After documentation of the FISH sites, the slides were washed according to procedure of Heslop-Harrison (2000) $(2 \times 45 \mathrm{~min}$ in $4 \times \mathrm{SSC}$ Tween and $2 \times 5 \mathrm{~min}$ in $2 \times \mathrm{SSC}$, at room temperature). Second FISH with pSc119.2 and pAs1 was made with the same conditions after reprobing followed by GISH carried out according to Kwiatek et al. (2012) with modifications. GISH experiments were performed using D-genome probe (from Ae. tauschii) and unlabelled triticale genomic DNA which was used as specific blocker. Multicolour GISH (mcGISH) was carried out using A-genome probe (from T. monococcum), D-genome probe (from Ae. tauschii) as well as unlabelled $A$ e. speltoides and $S$. cereale genomic DNA which were used as specific blockers. The GISH mixture $(40 \mu \mathrm{L}$ per slide), containing $50 \%$ formamide, $2 \times$ SSC, $10 \%$ dextran sulphate, $90 \mathrm{ng}$ each of the genome probes, and $4.5 \mu \mathrm{g}$ blocking DNA, was denatured at $75^{\circ} \mathrm{C}$ for $10 \mathrm{~min}$ and stored on ice for $10 \mathrm{~min}$. The chromosomal DNA denaturation, hybridization, and immunodetection conditions were the same as in FISH experiments. Mitotic cells were examined with an Olympus BX 61 automatic epifluorescence microscope with Olympus XM10 CCD camera. Image processing was carried out using the Olympus CellF (version 3.1; Olympus Soft Imaging Solutions GmbH: Münster, Germany) imaging software and PaintShop Pro X5 software (version 15.0.0.183; Corel Corporation, Ottawa, Canada). The identification of particular chromosomes was made by comparing the signal pattern of selected probes (5S rDNA, 25S rDNA, pSc119.2, and pAs1) according to a previous study (Kwiatek et al. 2013, 2015) and similar cytogenetic analysis (Cuadrado and Jouve 1994; Schneider et al. 2003, 2005; Wiśniewska et al. 2013).

\section{PCR amplification of SSR markers}

Genomic DNA was extracted from fresh leaves of single plants using GeneMATRIX Plant and Funghi DNA Purification Kit (EURx Ltd.). Total genomic DNAs of Ae. tauschii, $\times$ Triticosecale cv. Bogo, T. aestivum cv. Chinese Spring, $\mathrm{BC}_{2} \mathrm{~F}_{5}$, and $\mathrm{BC}_{2} \mathrm{~F}_{6}$ hybrids were used as templates for PCR. Analyses were performed with $25 \mu \mathrm{l}$ mixture according to Kwiatek et al. (2016a). PCR reactions were carried out in LabCycler thermocycler (SensoQuest Biomedizinische Elektronik, Goettingen, Germany) according to programs reported in GrainGenes 2.0 Database (http://wheat.pw.usda. gov/GG2/index.shtml) for every SSR marker. Amplification products were electrophoresed at $120 \mathrm{~V}$ for about $2 \mathrm{~h}$ in $2 \%$ agarose gel (Sigma), stained with ethidium bromide (Sigma), visualized under UV light and photographed (Syngen UV visualiser).

\section{Analysis of plant height, spike morphology, and effectiveness of self-pollinations}

Measurements of plants height were performed when plants reached maturity. There were measured the length of stem and spike separately for every stem of the plants (1-8), and the mean values were calculated. For every plant, the spike morphology was evaluated and all the spikes were archived by photography. After the harvest, grains from spikes were threshed and the mean effectiveness of sell-pollinations for every plant was calculated. The 
number of obtained seeds was divided by the number of flowers in spike and expressed as a percentage value. For triticale cv. Bogo, ten representative plants were subjected to analysis regarding all mentioned phenotypic features.

\section{Evaluation of powdery mildew infections}

During the vegetation period, the level of powdery mildew natural infection was evaluated according to COBORU (the Research Centre for Cultivar Testing) recommendations on a $9^{\circ}$ scale, where 9 is the most favourable state for agriculture. The means of powdery mildew expression scores in $\mathrm{BC}_{2} \mathrm{~F}_{5}$ and $\mathrm{BC}_{2} \mathrm{~F}_{6}$ hybrids, Ae. tauschii, and triticale 'Bogo' were compared each year to the results of PCR amplification of Pm43 marker using ANOVA calculations and Tukey's HSD test.

\section{Results}

\section{Identification of Ae. tauschii chromatin introgression in triticale hybrids}

The chromosome composition of (Ae. tauschii $\times S$. cereale) $\times$ triticale $\mathrm{cv}$. Bogo hybrids was performed using FISH and GISH. The analysis were made using FISH with 5S and 25S rDNA (Fig. 1a), pSc119.2 and pAs1 (Fig. 1b), GISH with D-genome probe, and blocking DNA from triticale (Fig. 1c), as well as mcGISH with A- and D-genome probes and blocking DNA from Ae. speltoides and rye (Fig. 1d). Identification of particular chromosomes of A-, B-, R-, and D-genome was made basing on previous reports of Cuadrado and Jouve (2002), Schneider et al. (2003, 2005) and Molnár et al. (2014), respectively, and chromosome arms ratio. The analysis of $\mathrm{F}_{1}$ to $\mathrm{BC}_{2} \mathrm{~F}_{3}$ generations was performed by Kwiatek et al. (2015) and revealed that one hybrid plant from $\mathrm{BC}_{2} \mathrm{~F}_{2}$ exhibited 46 chromosomes with additional pairs of $2 \mathrm{D}$ and $3 \mathrm{D}$ chromosomes. This plant was self-crossed to produce $\mathrm{BC}_{2} \mathrm{~F}_{3}$ generation. The analysis of the progeny revealed six plants with additional pairs of 2D and 3D chromosomes as well as four plants with the addition of single chromosomes $2 \mathrm{D}$ and four plants with single chromosome $3 \mathrm{D}$. The $\mathrm{BC}_{2} \mathrm{~F}_{4}$ to $\mathrm{BC}_{2} \mathrm{~F}_{6}$ plants in this study were obtained only from $\mathrm{BC}_{2} \mathrm{~F}_{3}$ genotypes characterized by constitution of 21 " +1 " $3 \mathrm{D}$ +1 "2D chromosomes by subsequent self-pollinations (Fig. 2). FISH experiments allowed to distinguish 1 plant of $\mathrm{BC}_{2} \mathrm{~F}_{4}$ with additional pair of $2 \mathrm{D}$ chromosomes. Eight plants of $\mathrm{BC}_{2} \mathrm{~F}_{5}$ generation consisted of five plants with introgression of single chromosome 2D. Another three plants carried one rearranged chromosome 2D considering the differences in pAs1 sequence signals pattern (Fig. 3). Furthermore, 36 plants of $\mathrm{BC}_{2} \mathrm{~F}_{6}$ generation were characterized by the presence of individual chromosome 2 of D-genome chromatin. Among $\mathrm{BC}_{2} \mathrm{~F}_{6}$ hybrid plants, twenty carried single chromosome $2 \mathrm{D}$, whereas sixteen carried one rearranged chromosome $2 \mathrm{D}$.

\section{SSR markers analysis specific for D-genome chromatin}

The analysis of molecular markers, specific for every D-genome chromosome according to wheat (T. aestivum $\mathrm{cv}$. Chinese Spring) genetic maps reported by Somers et al. (2004) (Xcfd19-1D; Xgwm301-2D; Xbarc71-3D; Xcfd714D; Xcfd10-5D; Xcfd49-6D; Xgwm428-7D) confirmed the FISH/GISH results. The presence of $2 \mathrm{D}$ chromosome in eight plants of $\mathrm{BC}_{2} \mathrm{~F}_{5}$ generation was confirmed in comparison with positive controls, which consists of Ae. tauschii and negative control of $\times$ Triticosecale cv. Bogo (Fig. 4). Furthermore, the organization of this chromosome was analyzed using 13 SSR markers (Xcfd56-2DS; Xgdm352DS; Xcfd51-2DS; Xwmc25-2DS; Xwmc503-2DS; Xgwm261-2DS; Xgwm296-2DS; Xgwm210-2DS; Xgwm4552DS; Xgwm102-2DS; Xgwm157-2DL; Xgwm539-2DL; Xgwm301-2DL) with special consideration of the short arm, where Rht 8 is located. SSR markers' analysis provided polymorphic sizes of bands considering three hybrid plants of $\mathrm{BC}_{2} \mathrm{~F}_{5}$ generation. It was revealed that the place of rearrangement occurred between markers $X c f d 51$ and $X g$ $w m 210$ in the short arm of $2 \mathrm{D}$ chromosome. The highest polymorphism was observed considering the sizes of amplification products of Xgwm261 marker which is linked to Rht 8 gene (Fig. 4). The occurrence of the rearrangement in this region was also observed in plants of the next generation $\left(\mathrm{BC}_{2} \mathrm{~F}_{6}\right)$. It is worth to mention that in the case of most SSR markers, the size of the bands differs between selected Ae. tauschii line D51 and T. aestivum cv. Chinese Spring, however, appropriate bands were not present in triticale cv. Bogo. Weak bands appeared in negative control considering Xgwm539, Xgwm301, Xgdm35, and Xgwm157 markers, which were detected in hybrid plants, as well.

\section{Evaluation of the influence of $2 \mathrm{D}$ chromosome addition on plant height and spike morphology}

In general, all monosomic alien addition plants of $\mathrm{BC}_{2} \mathrm{~F}_{5}$ generation were lower in comparison with triticale (Table 1). The mean height of hybrid plants was $68 \mathrm{~cm}$, whereas triticale plants were $26 \mathrm{~cm}$ higher $(94 \mathrm{~cm})$ what indicates about $28 \%$ of height reduction. All hybrid plants of $\mathrm{BC}_{2} \mathrm{~F}_{5}$ were treated as one group due to the small number of plants with $\mathrm{D}$-genome introgression. In turn, all $\mathrm{BC}_{2} \mathrm{~F}_{6}$ hybrids ( 36 plants) were divided into two groups: plants with chromosome $2 \mathrm{D}$ and plants which rearranged chromosome 2D according to the results of cytogenetic and 

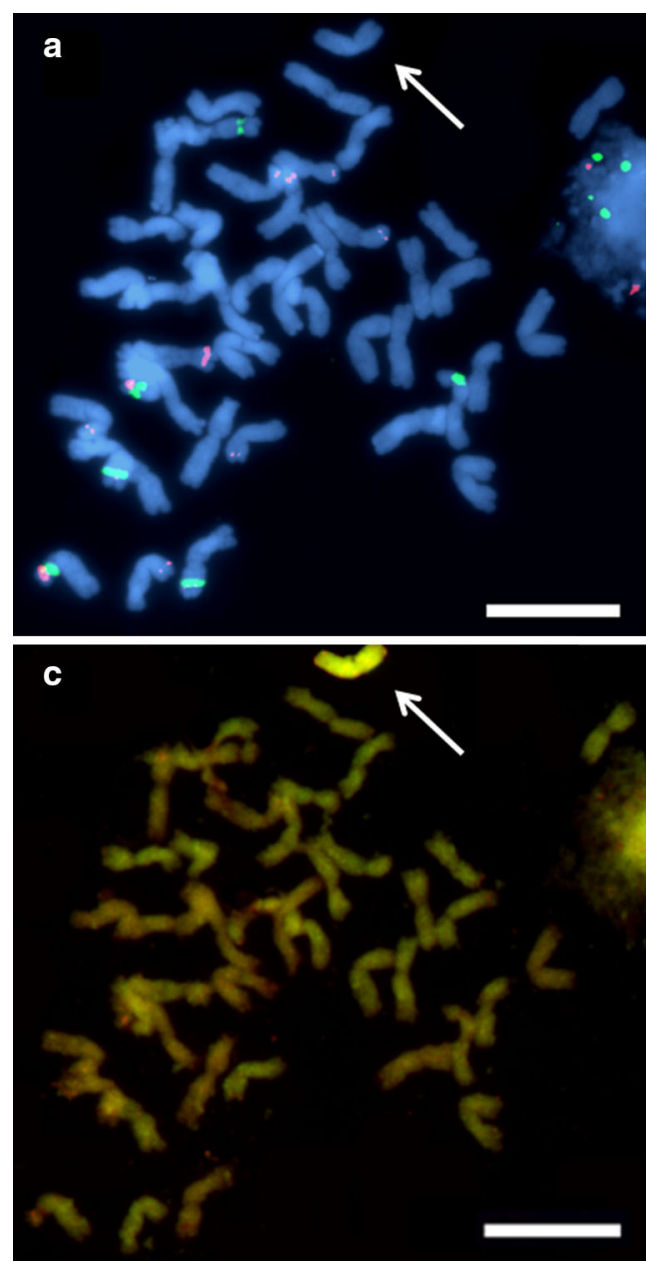

Fig. 1 Mitotic chromosomes of $\mathrm{BC}_{2} \mathrm{~F}_{5}$ (Ae. tauschii $\times S$. cereale $) \times$ Triticosecale cv. Bogo hybrid analyzed using a FISH with 5S rDNA (red) and 35S rDNA (green) probes, b FISH with pAs1 (red) and pSc119.2 (green) probes, c GISH with total genomic DNA probes of Ae. tauschii ( $\mathrm{D}$, green) and triticale (ABR, orange),

SSR markers analysis. This observation revealed that plants with chromosome 2D and rearranged chromosome 2D lead to the decrease of plant height of about 37 (39\%) and $12 \mathrm{~cm}(12.5 \%)$, respectively, in comparison with triticale $(96 \mathrm{~cm})$. When all hybrid plants of $\mathrm{BC}_{2} \mathrm{~F}_{6}$ were treated as one group, such as in previous season, the mean value and reduction of plant heights were similar in both years (data not shown). The spike morphology was normal among $\mathrm{BC}_{2} \mathrm{~F}_{5}$ hybrid plants in comparison with triticale cv. Bogo. In contrast, spikes of 16 hybrid plants of the next generation ( $22 \%$ of all hybrids of $\mathrm{BC}_{2} \mathrm{~F}_{6}$ generation) were characterized by the presence of supernumerary spikelets (SS) generally in the lower third of spike. However, there are also three plants which can be characterized by many additional spikelets along the whole length of the spikes (Fig. 5a). This trait in $\mathrm{BC}_{2} \mathrm{~F}_{6}$ generation of hybrids leads to the increased fertility $(64 \%)$ in comparison with hybrid plants demonstrating spikes similar to normal triticale
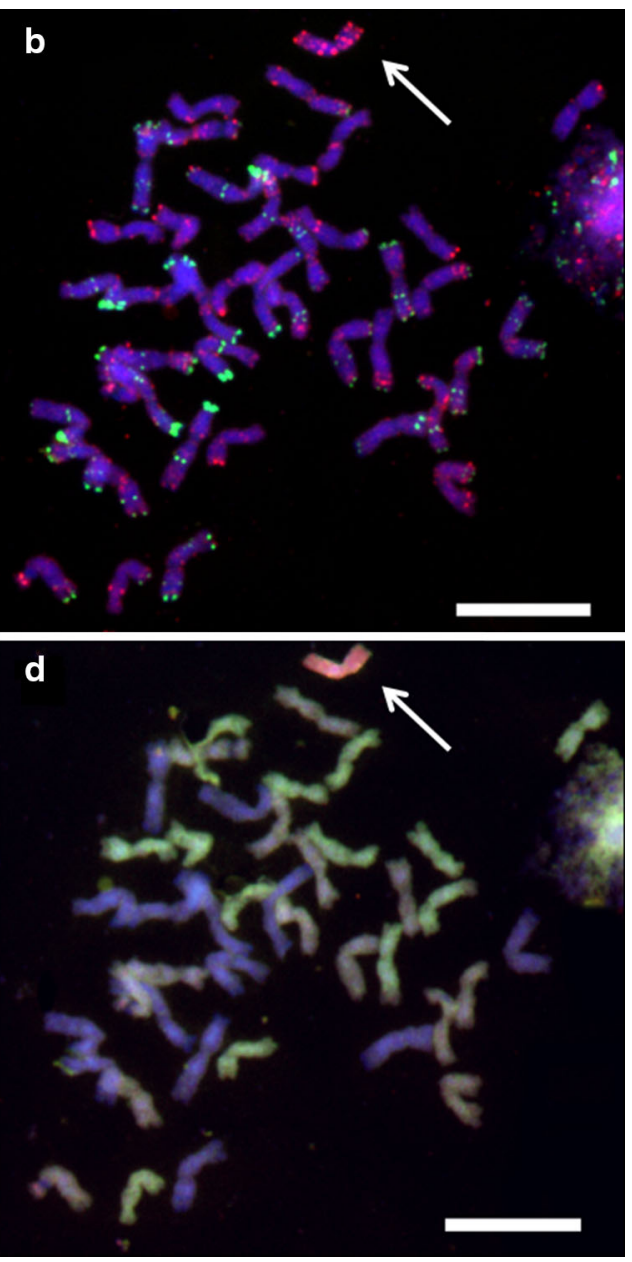

d multicolor GISH with total genomic DNA probes of T. monococcum (A, green), S. cereale and Ae. speltoides ( $\mathrm{R}$ and $\mathrm{B}$, blue), and Ae. tauschii (D, red). Arrows indicate the introgressed chromosome 2D. Scale bar $10 \mu \mathrm{m}$ (color figure online)

(46\%) (Fig. 5b), whereas triticale cv. Bogo (Fig. 5c) revealed high fertility $(90 \%)$ (Table 2$)$. Comparing the mean fertility values for both generations of hybrids, the obtained results were similar and indicate about $44 \%$ reduction of grains yield in comparison with triticale. Analysis with $\mathrm{Xgwm} 102$ marker localized nearby $m r s 1$ in bread wheat revealed that the amplification product of $150 \mathrm{bp}$ size was present in all analyzed hybrid plants and Ae. tauschii and was not present in triticale cv. Bogo.

\section{Evaluation of expression of the resistance to powdery mildew provided by $P m 43$ gene from $A e$. tauschii in triticale monosomic addition plants carrying 2D chromosome}

During the vegetation period, all analyzed plants of $A e$. tauschii exhibited low level of powdery mildew natural infection and mean scores ranged between 8.3 and 8.45 


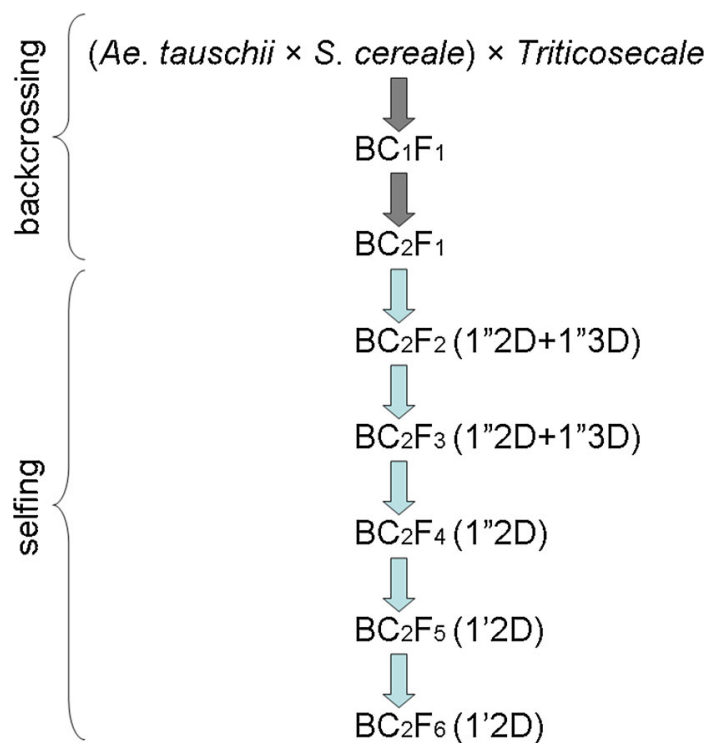

Fig. 2 Scheme of subsequent crosses between Aegilops tauschii $\times$ Secale cereale amphiploid forms and triticale cv. Bogo. The presence of D-genome chromosomes in subsequent generations was in brackets
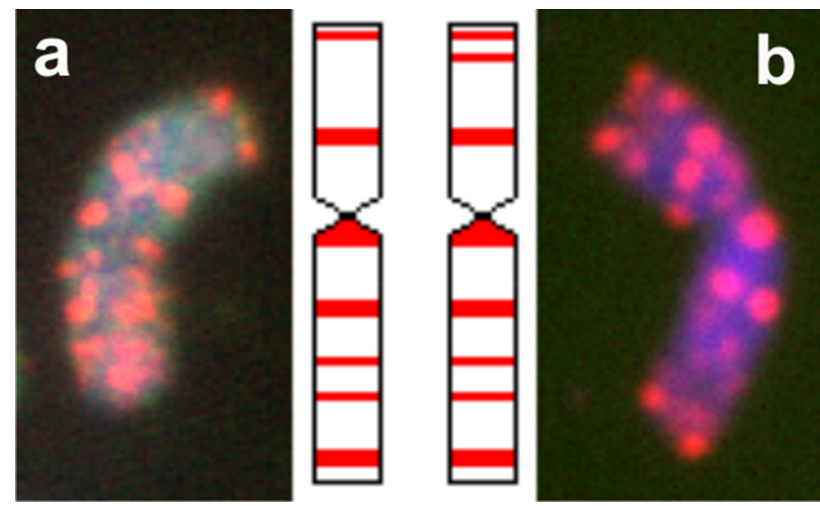

Fig. 3 Idiogram and karyotype of two types of additional chromosomes of Ae. tauschii detected in the background of $\mathrm{BC}_{2} \mathrm{~F}_{5}$ and $\mathrm{BC}_{2} \mathrm{~F}_{6}$ hybrids of triticale showing genomic distribution of repetitive DNA sequence pAs1 (red). a Normal chromosome 2D, b chromosome 2D with rearrangement (color figure online)

(Table 3). The observations of the infection symptoms conducted on all analyzed monosomic addition plants of $\mathrm{BC}_{2} \mathrm{~F}_{5}$ and $\mathrm{BC}_{2} \mathrm{~F}_{6}$ generations showed high tolerance to powdery mildew. There were no differences in resistance between hybrids carrying normal $2 \mathrm{D}$ and rearranged $2 \mathrm{D}$ chromosome. The mean scores of infection ranged between 7.63 and 7.97. In comparison, triticale cv. Bogo plants were less tolerant and the mean scores of the infection level ranged between 2.85 and 3.05 (Table 3 ). This observation was in accordance with the results of the SSR markers analysis with Xgwm539 marker, located on chromosome 2D of Ae. tauschii, which is one of the markers related to powdery mildew resistant gene Pm43 (Fig. 4). The amplification products of $150 \mathrm{bp}$ in size were found in DNA extracts of Ae. tauschii (positive control carrying Pm43) and all monosomic addition plants of $\mathrm{BC}_{2} \mathrm{~F}_{5}$ and $\mathrm{BC}_{2} \mathrm{~F}_{6}$ generations. There were no differences in resistance between hybrids carrying normal $2 \mathrm{D}$ and rearranged $2 \mathrm{D}$ chromosome. The marker for $P m 43$ was not identified in triticale 'Bogo' (negative control).

\section{Discussion}

The two groups of chromosomes within Triticeae tribe are considered to posses high density of genes (Conley et al. 2004). According to the literature, chromosome $2 \mathrm{D}$ of Aegilops tauschii especially carries the Rht 8 gene which determine semi-dwarfism feature and $P m 43$ gene related to the resistance to Blumeria graminis (Jia et al. 2013). Furthermore, this chromosome bears gene mrsl responsible for SS (supernumerary spikelets) trait in bread wheat (Dobrovolskaya et al. 2015). In this work, we investigate the influence of the 2D chromosome of Ae. tauschii in monosomic addition plants of triticale considering agronomically important traits.

One of our assumptions was to introduce $R h t 8$ gene determining semi-dwarfism in wheat to triticale using $A e$. tauschii monosomic addition lines, which will be employed for $2 \mathrm{R} / 2 \mathrm{D}$ substitution or translocation induction. In our work, we used Ae.tauschii $\times S$. cereale amphiploids as a bridge forms for the introgression of D-genome chromatin to triticale. Such a comprehensive approach was applied by Kwiatek et al. (2016a), who transfer the Pml3 gene from Ae. variabilis $\times S$. cereale amphiploids into triticale cv. Lamberto. The present results show that introgression of 2D chromosomes, bearing Rht8 gene, from Ae. tauschii into triticale chromosome complement was successful and led to the height reduction of monosomic alien addition plants. Furthermore, this feature was maintained in the subsequent generations of hybrid plants. All monosomic alien addition plants, namely, 8 of $\mathrm{BC}_{2} \mathrm{~F}_{5}$ and 36 plants of $\mathrm{BC}_{2} \mathrm{~F}_{6}$, for which PCR amplification revealed bands for Xgwm261 marker, were substantially lower than triticale. The presence of the Ae. tauschii type band (200 bp) in hybrids can be associated with the reduction of height of about $37 \mathrm{~cm}$ in comparison with triticale cv. Bogo which mean height was $96 \mathrm{~cm}$. Similarly, 16 hybrids in which rearrangement event took place were also lower than triticale; however, the mean reduction of height was $12 \mathrm{~cm}$ only (Table 1). The presence of $R h t 8$ in wheat leads up to $10 \mathrm{~cm}$ reduction of the European varieties (Worland et al. 1998); however, T. aestivum is lower than triticale generally because of the presence of the remaining semidwarfism genes. The absence of these genes with the presence of the "alien" semi-dwarfism gene Rht 8 in winter 

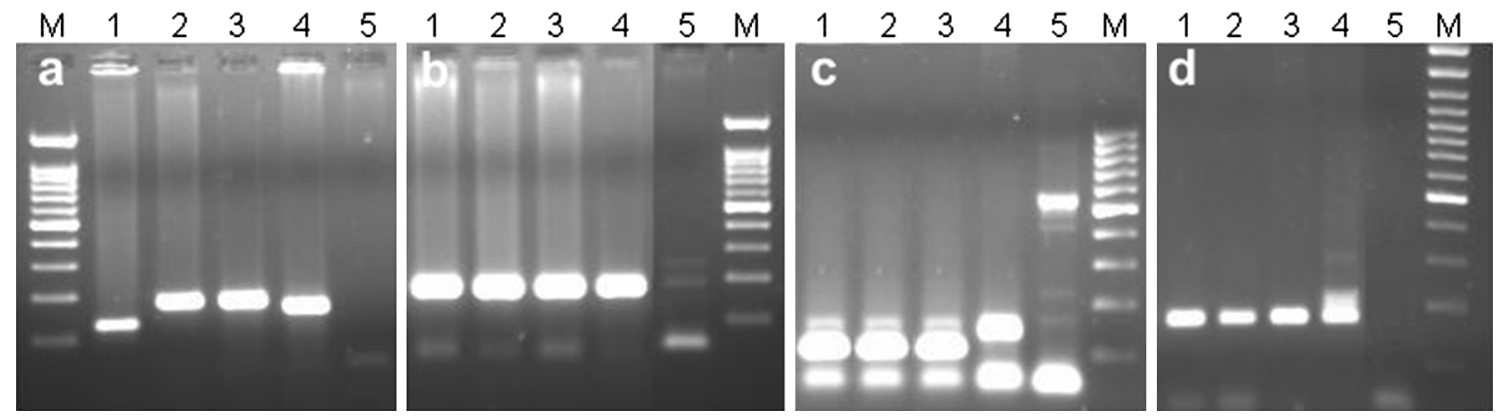

Fig. 4 Molecular analysis of selected SSRs specific for chromosome 2D in genomes of hybrid plants with a rearranged chromosome 2D; a Xgwm261, b Xgwm301, c Xgwm539, d Xgwm210; hybrid plants with rearranged 2D chromosome (1), hybrid plants with whole 2D chromosome (2), Ae. tauschii (3), T. aestivum cv. Chinese Spring (4) and triticale cv. Bogo (5). Marker $(M)$ size 100 bp
Table 1 Analysis of $\mathrm{BC}_{2} \mathrm{~F}_{5}$, $\mathrm{BC}_{2} \mathrm{~F}_{6}$, and parental form triticale cv. Bogo plant height

\begin{tabular}{lllll}
\hline Generation & $\begin{array}{l}\text { Number of } \\
\text { plants }\end{array}$ & $\begin{array}{l}\text { Mean } \\
\text { height }(\mathrm{cm})\end{array}$ & $\begin{array}{l}\text { Range of plants } \\
\text { height }(\mathrm{cm})\end{array}$ & $\begin{array}{l}\text { Mean reduction } \\
\text { of height }(\mathrm{cm})\end{array}$ \\
\hline $\mathrm{BC}_{2} \mathrm{~F}_{5}$ (2D addition lines) & 8 & 68 & $46-92$ & 26 \\
$\mathrm{BC}_{2} \mathrm{~F}_{5}$ (without D chromatin) & 21 & 88 & $79-96$ & 6 \\
Triticale cv. Bogo & 20 & 94 & $86-101$ & N/A \\
$\mathrm{BC}_{2} \mathrm{~F}_{6}$ (whole chromosome 2D) & 20 & 59 & $43-70$ & 37 \\
$\mathrm{BC}_{2} \mathrm{~F}_{6}$ (2D with rearrangement) & 16 & 84 & $68-98$ & 12 \\
$\mathrm{BC}_{2} \mathrm{~F}_{6}$ (without D chromatin) & 36 & 90 & $83-101$ & 6 \\
Triticale cv. Bogo & 20 & 96 & $89-104$ & N/A \\
\hline
\end{tabular}

The table represents mean height, range of plant height, and the observed reduction of height in the subsequent generation of plants triticale is most likely the general reason of such high decreasing of plants height. Furthermore, our analysis revealed differences in size of amplification products of Xgwm261 marker between positive controls-Ae. tauschii and $T$. aestivum cv. Chinese Spring. The amplification products of $200 \mathrm{bp}$ in size were characteristic to Ae. tauschii and monosomic alien addition plants of $\mathrm{BC}_{2} \mathrm{~F}_{5}$ and $\mathrm{BC}_{2} \mathrm{~F}_{6}$ generations. SSR analysis of hybrid plants carrying rearranged $2 \mathrm{D}$ chromosome revealed amplification products of about $140 \mathrm{bp}$. Band of predicted size $192 \mathrm{bp}$ was obtained for DNA of positive control 'Chinese Spring'. The marker for $R h t 8$ was not identified in triticale cv. Bogo. That observations indicate that Ae. tauschii posses different alleles of $R h t 8$ gene, where wheat 'Chinese Spring' can be characterized by the most frequent allele Rht8c. According to McIntosh et al. (2003) analyzed Ae. tauschii accession might posses allele Rht8d (201 bp) because of the similarity of amplification product size.

Monosomic addition lines of triticale carrying chromosome 2D were also investigated in terms of powdery mildew resistance identification. According to Jia et al. (2013), a powdery mildew resistance gene Pm43 was mapped on the $2 \mathrm{D}$ chromosome of wheat. The molecular marker analysis and the visual evaluation of powdery mildew symptoms in Ae. tauschii revealed the presence of Pm43 marker (Xgwm539) and low powdery mildew reaction, confirmed by infection scores made on 20 plants each year of the experiment (Table 3). Similarly, monosomic alien addition plants of the $\mathrm{BC}_{2} \mathrm{~F}_{5}$ and $\mathrm{BC}_{2} \mathrm{~F}_{6}$ generations were highly tolerant to powdery mildew infection and possessed Pm43 marker. A lack of the differences in resistance between hybrids with additional $2 \mathrm{D}$ and rearranged $2 \mathrm{D}$ chromosome is related to the localization of the Pm43 marker on the long arm of chromosome 2D. In comparison, triticale 'Bogo' was much more infected, which was confirmed by Tukey's HSD test (Table 3). It is in accordance with the results of Czembor et al. (2013) who reported that triticale 'Bogo' is susceptible to all isolates of Blumeria graminis derived from triticale. Furthermore, the molecular analysis showed that Pm43 marker was not present in triticale 'Bogo' (Fig. 4; Table 3). Pm43 gene was mapped on the basis of CH5025 $\times$ CH5065 2DL population source map (Jia et al. 2013). CH5025 was a Th. intermediumderived line of wheat resistant to powdery mildew, whereas CH5065 is susceptible line (He et al. 2009). On this basis, it can be assumed that the region determining resistance to powdery mildew in Th. intermedium is homologous in Ae. tauschii what is consistent with observations of $\mathrm{He}$ et al. (2009) about chromosome pairing of D-genome of wheat and $\mathrm{J}$ or $\mathrm{J}^{\mathrm{s}}$ chromosomes of Th. intermedium. Furthermore, 

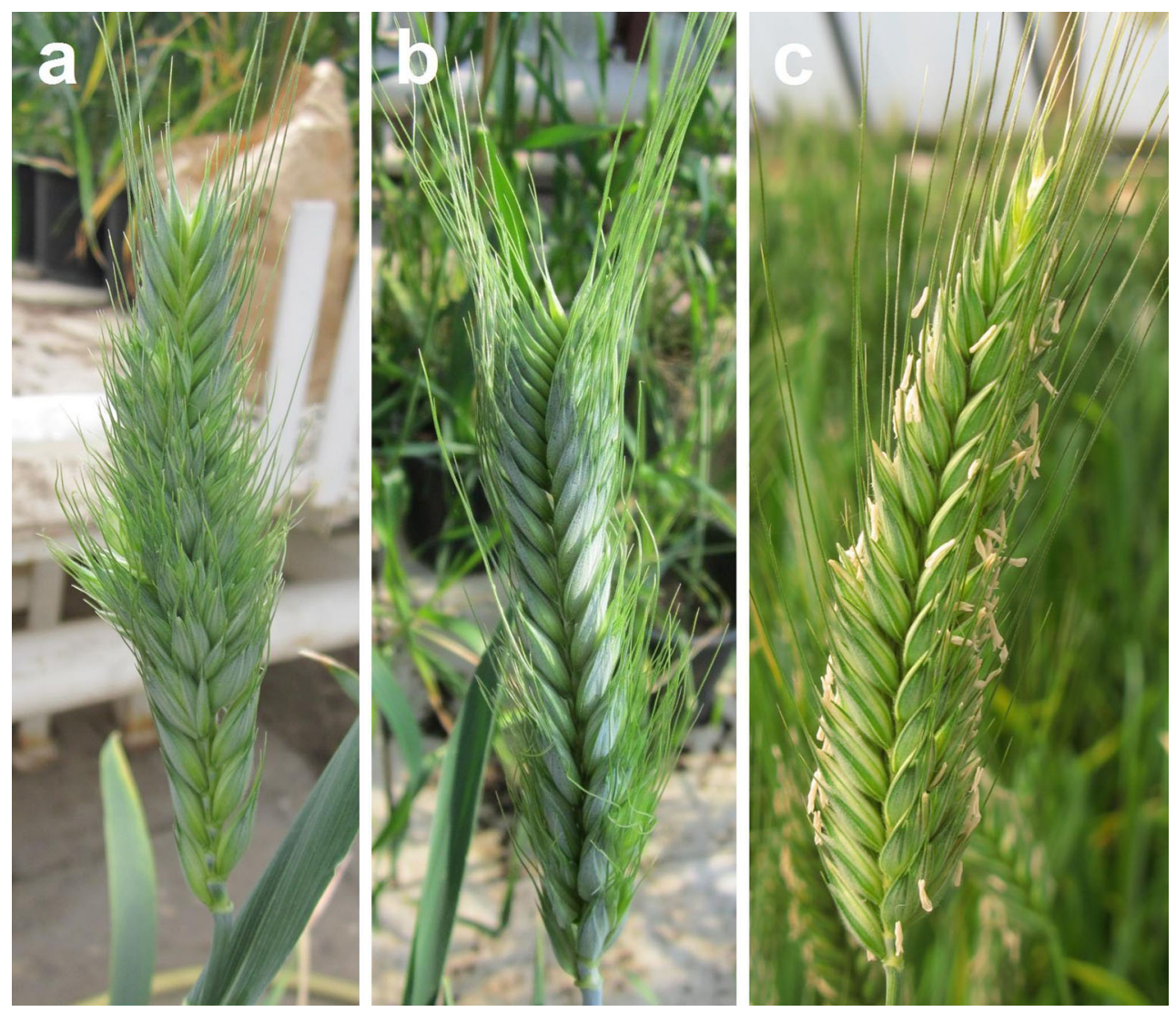

Fig. 5 Spikes morphology of the analyzed plants. Spikes of the $\mathrm{BC}_{2} \mathrm{~F}_{6}$ hybrids $($ Ae. tauschii $\times$ S. cereale $) \times$ Triticosecale cv. Bogo demonstrating a the presence of supernumerary spikelets and $\mathbf{b}$ morphology similar to triticale; $\mathbf{c}$ appropriate spike of the triticale $\mathrm{cv}$. Bogo

Table 2 Analysis of $\mathrm{BC}_{2} \mathrm{~F}_{5}, \mathrm{BC}_{2} \mathrm{~F}_{6}$, and parental form triticale cv. Bogo fertility

\begin{tabular}{lcll}
\hline Generation & $\begin{array}{l}\text { Number } \\
\text { of plants }\end{array}$ & $\begin{array}{l}\text { Self-pollination } \\
\text { effectiveness (\%) }\end{array}$ & $\begin{array}{l}\text { Range } \\
(\%)\end{array}$ \\
\hline $\mathrm{BC}_{2} \mathrm{~F}_{5}$ (2D addition lines) & 8 & 42 & $15-81$ \\
$\mathrm{BC}_{2} \mathrm{~F}_{5}$ (without D chromatin) & 21 & 70 & $50-81$ \\
Triticale cv. Bogo & 20 & 86 & $80-93$ \\
$\mathrm{BC}_{2} \mathrm{~F}_{6}$ (all spikes) & 72 & 46 & $17-83$ \\
$\mathrm{BC}_{2} \mathrm{~F}_{6}$ (spikes with SS) & 16 & 64 & $41-83$ \\
Triticale cv. Bogo & 20 & 90 & $81-95$ \\
\hline
\end{tabular}

The table represents the mean and range of the effectiveness of selfpollinations in the subsequent generation of plants

in both the species as well as in obtained hybrids, the resistance was maintained at both the stages of development. The successful transfer of 2D chromosomes and positive effect of powdery mildew resistance in triticale proved that Ae. tauschii is more valuable source of this gene for breeding programs because of the simplest genome composition and closer relationship with traditional crops, rather than Th. intermedium.

Our work revealed a rearrangement of chromosome considering additional chromosome $2 \mathrm{D}$ in the subsequent generations of triticale plants. The chromosome aberrations appeared between markers Xcfd51 and Xgwm210 in the short arm of chromosome 2D. This region is notably important forasmuch, and there is localized semi-dwarfing gene $R h t 8$. The changes in organization of $2 \mathrm{D}$ chromosome had direct influence on plant height of triticale hybrids, what might be connected with changes in Rht8 loci which is localized nearby Xgwm261. Although the occurrence of rearrangement was unexpected in such advance generations of plants, its localization in chromosome is not random and might be explained by the evolution of Ae. tauschii genome. According to the literature, based on the sequencing data, it was hypothesized that the seven chromosomes of this species originated from 12 ancestral chromosomes by five nested chromosome insertions (NCIs). During the NCIs, a telomere of the inserted chromosome was inserted near the centromere in a gene-containing region. As a result of NCIs, one of the centromere was lost, and the centromere of the inserted chromosome became the active centromere in each compound chromosome. Chromosome 2D of Ae. tauschii was produced as a result of the NCIs. Therefore, it might be concluded that examined in this research region is specially exposed to chromosome rearrangements and such places in genome 
Table 3 Evaluation of the natural infection level caused by $B$. graminis on the $\mathrm{BC}_{2} \mathrm{~F}_{5}$ and $\mathrm{BC}_{2} \mathrm{~F}_{6}$ hybrids of (Ae. tauschii $\times S$. cereale $) \times$ triticale 'Bogo'

\begin{tabular}{|c|c|c|c|c|c|c|c|c|}
\hline \multirow[t]{3}{*}{ Generation } & & \multicolumn{7}{|c|}{ Number of plants } \\
\hline & & \multicolumn{3}{|c|}{ With $P m 43$ marker } & & \multicolumn{3}{|c|}{ Without $P m 43$ marker } \\
\hline & & \multicolumn{2}{|l|}{ Ae. tauschii } & Hybrids & \multicolumn{2}{|c|}{ Triticale 'Bogo' } & & Hybrids \\
\hline $\mathrm{BC}_{2} \mathrm{~F}_{5}$ & & \multicolumn{2}{|l|}{20} & 8 & \multicolumn{2}{|c|}{20} & & 21 \\
\hline $\mathrm{BC}_{2} \mathrm{~F}_{6}$ & & \multicolumn{2}{|l|}{20} & 36 & \multicolumn{2}{|c|}{20} & & 36 \\
\hline \multirow[t]{3}{*}{ Generation } & & \multicolumn{7}{|c|}{ Means (range) of infection scores } \\
\hline & & \multicolumn{3}{|c|}{ With Pm43 marker } & & \multicolumn{3}{|c|}{ Without Pm43 marker } \\
\hline & & \multicolumn{2}{|l|}{ Ae. tauschii (1) } & Hybrids (2) & \multicolumn{2}{|c|}{ Triticale 'Bogo' (3) } & & Hybrids (4) \\
\hline $\mathrm{BC}_{2} \mathrm{~F}_{5}$ & & \multicolumn{2}{|l|}{$8.3(8-9)$} & $7.63(7-9)$ & \multicolumn{2}{|c|}{$2.85(2-4)$} & & $3.33(2-4)$ \\
\hline $\mathrm{BC}_{2} \mathrm{~F}_{6}$ & & \multicolumn{2}{|l|}{$8.45(8-9)$} & $7.97(7-9)$ & \multicolumn{2}{|c|}{$3.05(2-4)$} & & $3.44(2-4)$ \\
\hline \multirow[t]{2}{*}{ Generation } & \multicolumn{2}{|c|}{ HSD level } & 1 vs 2 & 1 vs 3 & 1 vs 4 & 2 vs 3 & 2 vs 4 & 3 vs 4 \\
\hline & $\mathrm{HSD}_{0.05}$ & $\mathrm{HSD}_{0.01}$ & & & & & & \\
\hline \multicolumn{9}{|c|}{ Tukey's honest significant difference (HSD) test } \\
\hline $\mathrm{BC}_{2} \mathrm{~F}_{5}$ & 0.63 & 0.77 & $P<0.05$ & $P<0.01$ & $P<0.01$ & $P<0.01$ & $P<0.01$ & NS \\
\hline $\mathrm{BC}_{2} \mathrm{~F}_{6}$ & 0.46 & 0.57 & $P<0.05$ & $P<0.01$ & $P<0.01$ & $P<0.01$ & $P<0.01$ & NS \\
\hline
\end{tabular}

may constitute a hot spots. Furthermore, the heat map of the recombination rates showed that the recombination rate for this region is relatively high (Luo et al. 2009, 2013). That might be the reason of rearrangement events which occur especially during stress conditions, such as integration of the alien chromatin into hybrid plants or backcrossing.

The results of this research showed that the presence of additional chromosomes 2D induces changes in spike morphology of triticale hybrid plants. However, measurements of spikes revealed any significant differences in the length of the spike in hybrid plants (data not shown). Most of the analyzed plants were characterized by the presence of spikes which morphology was congenial to triticale spike what should be expected in advanced generations of hybrids (Fig. 5b). However, about $22 \%$ of $\mathrm{BC}_{2} \mathrm{~F}_{6}$ generation plants posses spikes with supernumerary spikelets, a trait which was already reported only for wheat, where the MRS trait is under the control of a recessive allele at a single locus located on chromosome 2D (Dobrovolskaya et al. 2015). The presence of $b h-D l$, a multirow spike recessive allele (alias $m r s l$ ), was also reported for $A e$. tauschii (Jia et al. 2013). SSR marker analysis with $X g$ wm102 marker revealed amplification products of $150 \mathrm{bp}$ in size for Ae. tauschii and unexpectedly for all hybrid plants. Considering the obtained results and wheat origin of this SSR marker (genetic distance $1.3 \mathrm{cM}$ ), it was assumed that this marker is not suitable to analyze the SS trait in hybrid plants of Ae. tauschii and triticale. This relevance proves that the genetic distance between $b h-D l$ and
Xgwm102 marker on map reported by Jia et al. (2013) is $9.43 \mathrm{cM}$ which indicates that this markers in not combined with SS trait in Ae. tauschii. It is also important that this recessive trait in triticale hybrids was conditioned only by the presence of single chromosome 2D which is consistent with the observations of Sears (1954), who report the reduplication of spikelets in hexaploid wheat plants nullisomic for this chromosomes. The occurrence of SS trait in analyzed plants leads to the increase of grain yield in comparison with the rest pool of plants (Table 2). These observations allowed to conclude that such a approach may allow new spike architectures of triticale to be designed, with the aim of enhancing grain production.

In conclusion, monosomic alien addition plants obtained here provide a feasible platform to identify and estimate valuable traits for triticale breeding using molecular cytogenetics, screening of forms with SSR markers combined with phenotype analysis, and evaluation of powdery mildew infection. Using these methods, we have obtained 20 semi-dwarf plants of $\mathrm{BC}_{2} \mathrm{~F}_{6}$ generation carrying $2 \mathrm{D}$ chromosome with the powdery mildew resistance, without changes in spike morphology which can be used in the triticale breeding programs. Furthermore, the limitations of reports about transferring the powdery mildew resistance genes as well as genes determining semi-dwarfism and spike morphology to triticale indicate that there is a great legitimacy and potential in the field of using monosomic addition plants carrying chromosomes of Ae. tauschii to improve this valuable crop. From the other hand, the molecular analysis of triticale monosomic alien addition 
plants provided significant insights considering the organization changes of additional chromosome induced by the integration of the alien chromatin in triticale genetic background.

Acknowledgments We would like to gratefully acknowledge the technical assistance of Mrs. Grażyna Cicha and Mrs. Joanna Maszner. This work was financed by the National Science Centre (DEC-2014/ 15/N/NZ9/00448).

Author contribution statement MM., M.K., and H.W. initiated the project and designed the study. M.K., M.M., and J.B. performed the research. M.M. wrote the paper. All authors read and approved the manuscript.

\section{Compliance with ethical standards}

Conflict of interest The authors declare that they have no conflict of interest.

Open Access This article is distributed under the terms of the Creative Commons Attribution 4.0 International License (http://crea tivecommons.org/licenses/by/4.0/), which permits unrestricted use, distribution, and reproduction in any medium, provided you give appropriate credit to the original author(s) and the source, provide a link to the Creative Commons license, and indicate if changes were made.

\section{References}

Arseniuk E, Góral T (2015) Chapter 5. Triticale biotic stresses-known and novel foes, In: Eudes F (ed.), Triticale, Springer International Publishing, Berlin, p 83-108

Cho S, Garvin DF, Muehlbauer GJ (2006) Transcriptome analysis and physical mapping of barley genes in wheat-barley chromosome addition lines. Genetics 172:1277-1285

Conley et al (2004) A 2600-locus chromosome bin map of wheat homoeologous group 2 reveals interstitial gene-rich islands and colinearity with rice. Genetics 168:625-637

Cuadrado A, Jouve N (1994) Mapping and organization of highly repeated DNA sequences by means of simultaneous and sequential FISH and C-banding in 6x-triticale. Chromosome Res 2:331-338

Cuadrado A, Jouve N (2002) Evolutionary trends of different repetitive dna sequences during speciation in the genus Secale. J Hered 93:339-345

Czembor HJ, Doraczyńska O, Czembor JH (2013) In Polish: Odporność odmian pszenżyta na mączniaka prawdziwego (Blumeria graminis ff. ssp.) występującego w Polsce (Resistance of triticale cultivars to powdery mildew (Blumeria graminis ff. ssp.) occurring in Poland). Biuletyn Instytutu Hodowli i Aklimatyzacji Roślin 267:3-16

Dobrovolskaya O et al (2015) FRIZZY PANICLE drives supernumerary spikelets in bread wheat. Plant Physiol 167:189-199

FAOSTAT (2015) Production Crops. (http://faostat.fao.org/site/567/ DesktopDefault.aspx?PageID=567\#ancor). Accessed 20 Nov 2015

Foulkes MJ, Slafer GA, Davies WJ, Berry PM, Sylvester-Bradley R, Martre P, Calderini DF, Griffiths S, Reynolds MP (2011) Raising yield potential of wheat. III. Optimizing partitioning to grain while maintaining lodging resistance. J Exp Bot 62:469-486

Hasterok R, Dulawa J, Jenkins G, Leggett M, Langdon T (2006) Multisubstrate chromosome preparations for high throughput comparative FISH. BMC Biotechnol 6:1-5
He R, Chang Z, Yang Z, Yuan Z, Zhan H, Zhang X, Liu J (2009) Inheritance and mapping of powdery mildew resistance gene Pm43 introgressed from Thinopyrum intermedium into wheat. Theor Appl Genet 118:1173-1180

Hedden P (2003) The genes of the Green Revolution. Trends in Genetics 19:5-9

Heslop-Harrison JS (2000) Comparative genome organization in plants: from sequence and markers to chromatin and chromosomes. Plant Cell 12:617-635

Jia et al (2013) Aegilops tauschii draft genome sequence reveals a gene repertoire for wheat adaptation. Nature 496:91-95

Korzun V, Roder MS, Ganal MW, Worland AJ, Law CN (1998) Genetic analysis of the dwarfing gene $(R h t 8)$ in wheat. Part I. Molecular mapping of Rht8 on the short arm of chromosome 2D of bread wheat (Triticum aestivum L.). Theor Appl Genet 96:1104-1109

Książczyk T, Apolinarska B, Kulak-Książczyk S, Wiśniewska H, Stojałowski S, Łapiński M (2011) Identification of the chromosome complement and the spontaneous $1 \mathrm{R} / 1 \mathrm{~V}$ translocations in allotetraploid Secale cereale $\times$ Dasypyrum villosum hybrids through cytogenetic approaches. J Appl Genet 52:305-311

Kwiatek M, Błaszczyk L, Wiśniewska H, Apolinarska B (2012) Aegilops-Secale amphiploids: chromosome categorisation, pollen viability and identification of fungal disease resistance genes. J Appl Genet 53:37-40

Kwiatek M, Wiśniewska H, Apolinarska B (2013) Cytogenetic analysis of Aegilops chromosomes, potentially usable in triticale ( $\times$ Triticosecale Witt.) breeding. J Appl Genet 54:147-155

Kwiatek M, Majka M, Wiśniewska H, Apolinarska B, Belter J (2015) Effective transfer of chromosomes carrying leaf resistance genes from Aegilops tauschii Coss. into hexaploid triticale (X Triticosecale Witt.) using Ae. tauschii $\times$ Secale cereale amphiploid form. J Appl Genet 56:163-168

Kwiatek M, Belter J, Majka M, Wiśniewska H (2016a) Allocation of the S-genome chromosomes of Aegilops variabilis Eig. carrying powdery mildew resistance in triticale $(\times$ Triticosecale Wittmack). Protoplasma 253:329-343

Kwiatek M, Majka M, Ślusarkiewicz-Jarzina A, Ponitka A, Pudelska H, Belter J, Wiśniewska H (2016b) Inheritance of the Aegilops ovata chromosomes carrying gametocidal factors in hexaploid triticale ( $\times$ Triticosecale Wittm.) hybrids. J Appl Genet. doi:10. 1007/s13353-015-0332-3

Kynast RG, Okagaki RJ, Galatowitsch MW, Granath SR, Jacobs MS, Stec AO, Rines HW, Phillips RL (2004) Dissecting the maize genome by using chromosome addition and radiation hybrid lines. Proc Natl Acad Sci USA 101:9921-9926

Liu SB, Wang HG (2005) Characterization of a wheat-Thinopyron intermedium substitution line with resistance to powdery mildew. Euphytica 143:229-233

Liu SB, Wang HG, Zhang XY, Li XF, Li DY, Duan XY, Zhou YL (2005) Molecular Cytogenetic identification of a wheat-Thinopyron intermedium (Host) Barkworth and DR Dewey partial amphiploid resistant to powdery mildew. J Integr Plant Biol 47:726-733

Luo MC et al (2009) Genome comparisons reveal a dominant mechanism of chromosome number reduction in grasses and accelerated genome evolution in Triticeae. PNAS 106:15780-15785

Luo MC et al (2013) A 4-gigabase physical map unlocks the structure and evolution of the complex genome of Aegilops tauschii, the wheat D-genome progenitor. PNAS 110:7940-7945

McIntosh RA, Yamazaki Y, Devos KM, Dubcovsky J, Rogers WJ et al. (2003) Catalogue of gene symbols for wheat. In: Pogna NE, Romano M, Pogna E, Galterio G (eds.) Proceedings of the 10th International Wheat Genetics Symposium, Vol. 4, Instituto Sperimentale per la Cerealicotura, Rome, p 1-34 
Molnár I, Kubaláková M, Šimková H, Farkas A, Cseh A, Megyeri M, Vrána J, Molnár-Láng M, Doležel J (2014) Flow cytometric chromosome sorting from diploid progenitors of bread wheat, $T$. urartu, Ae. speltoides and Ae. tauschii. Theor Appl Genet 127:1091-1104

Ogbonnaya FC, Halloran GM, Lagudah ES (2005) D genome of wheat-60 years on from Kihara, Sears and McFadden. In: Tsunewaki K (ed) Frontiers of Wheat Bioscience. Kihara memorial foundation for the advancement of life sciences, Yokohama

Schneider A, Linc G, Molnár-Láng M (2003) Fluorescence in situ hybridization polymorphism using two repetitive DNA clones in different cultivars of wheat. Plant Breed 122:396-400

Schneider A, Linc G, Molnár I, Molnár-Lang M (2005) Molecular cytogenetic characterization of Aegilops biuncialis and its use for the identification of 5 derived wheat-Aegilops biuncialis addition lines. Genome 48:1070-1082

Sears ER (1954) The aneuploids of common wheat. University of Missouri, Columbia, pp 3-58
Somers DJ, Isaac P, Edwards K (2004) A high-density microsatellite consensus map for bread wheat (Triticum aestivum L.). Theor Appl Genet 109:1105-1114

Wiśniewska H, Kwiatek M, Kulak-Książczyk S, Apolinarska B (2013) Introgression of A- and B-genome chromatin into tetraploid rye (Secale cereale L.). J Appl Genet 54:435-440

Worland AJ, Korzun V, Roder MS, Ganal MW, Law CN (1998) Genetic analysis of the dwarfing gene Rht 8 in wheat. Part II. The distribution and adaptive significance of allelic variants at the Rht8 locus of wheat as revealed by microsatellite screening. Theor Appl Genet 96:1110-1120

Zhan HX, Li GR, Zhang XJ, LI X, Guo HJ, Gong WP, Jia JQ, Qiao LY (2014) Chromosomal location and comparative genomics analysis of powdery mildew resistance gene $P m 51$ in a putative wheat-Thinopyrum ponticum introgression line. PLoS One 9:e113455 